\title{
at RISALAHH
}

DOI: 10.24014/jdr.v31i1.9949

\section{FENOMENA KOMUNIKASI MUSLIMAT BERCADAR MELALUI MEDIA SOSIAL DI PEKANBARU}

\author{
Adriani Rahmida Hayati ${ }^{1}$, Yasir $^{2}$, Noor Efni Salam ${ }^{3}$ \\ ${ }^{1,2,3}$ Fakultas Ilmu Sosial dan Politik Universitas Riau \\ *Email:midadriani89@gmail.com
}

\section{Kata kunci}

Konsep diri, media sosial, motif, muslimat, cadar
Keywords

Self-concept, social media, motives, Muslim women, veils

\begin{abstract}
Abstrak
Penelitian ini bertujuan mendeskripsikan fenomena komunikasi muslimat bercadar di Kota Pekanbaru dalam menggunakan media sosial. Penelitian ini mengungkapkan pengalaman komunikasi, konsep diri, dan motif muslimat bercadar melalui penggunaan media sosial, dengan metode kualitatif dan pendekatan fenomenologi. Hasil penelitian menunjukkan bahwa pengalaman komunikasi muslimat bercadar menggunakan media sosial dari berbagai aspek, dengan pengalaman terbaik yang bertemu dengan orang baru sesama muslim, hingga pengalaman tidak menyenangkan dinilai sebagai teroris. Konsep diri mereka dalam penggunaan media sosial yaitu menciptakan konsep diri yang positif dengan sifat yang ramah, karena agama Islam mengajarkan hubungan yang baik sesama umat muslim seperti yang disunahkan Rasulullah. Motif lainnya, muslimat bercadar menggunakan media sosial sebagai sarana promosi untuk usaha, memperoleh kajian agama, serta komunikasi untuk keyakinan pemahaman agama.
\end{abstract}

\begin{abstract}
This study aims to describe the phenomenon of veiled Muslim woman communication in Pekanbaru in using social media. This research reveals communication experiences, self-concepts, and motives of Muslim veils through the use of social media, with qualitative methods and phenomenological approaches. The results showed that the experience of veiled Muslim woman communication using social media from various aspects, with the best experience of meeting new fellow Muslims, so that the unpleasant experience was considered a terrorist. Their self-concept in the use of social media is to create a positive self-concept with a friendly nature because Islam teaches a good relationship among Muslims as the sunnah of the Prophet. Another motive, veiled Muslim women, is to use social media as a means of promotion for businesses, obtain religious studies, as well as communication for understanding religious beliefs.
\end{abstract}

\section{Pendahuluan}

Wanita muslimat di Indonesia sudah banyak yang menggunakan hijab. Hijab itu sendiri merupakan cara menutup aurat dengan menutupi kepala dan leher, tetapi wajah tetap tampak. Perintah mengenakan jilbab terdapat dalam Al-Qur'an surat Al-Azhab ayat 59: Hendaklah mereka mengulurkan jilbabnya ke seluruh tubuh mereka. 
Perkembangannya di Indonesia, banyak dijumpai muslimat memakai penutup aurat dengan cadar. Muslimat yang memiliki keyakinan memilih untuk lebih menutup aurat dengan memakai cadar.

Cadar adalah istilah umum untuk kain hijab penutup wajah. Muslimat yang berjilbab longgar menggunakan cadar untuk menutup sebagian wajah. Mereka menggunakan cadar untuk menghindari pandangan orang-orang yang melihat, serta menjaga diri dan perilaku. Novri \& Yohana (2016) menjelaskan, bagi muslimat bercadar, cadar dipandang sebagai perintah agama yang hukumnya dimaknai sebagai hal yang wajib dan juga sunnah. Cadar juga dimaknai sebagai kebutuhan, kenyamanan psikologi, seperti halnya pakaian yang menutup tubuh manusia sehari-hari. Bagi penggunanya, cadar merupakan kebutuhan pokok yang tidak dapat ditinggalkan. Menurut mereka, menggunakan cadar dapat memberikan rasa nyaman, aman serta pengontrol diri.

Persoalan hijab ini ditinjau dari segi wajib tidaknya menutup wajah dan dua telapak tangan mempunyai dua filosofi yang berlainan. Jika dikatakan menutup wajah dan dua telapak tangan itu wajib, berarti pada hakikatnya kita telah menjadi pendukung filosofi yang mengatakan wajibnya "memingit" perempuan dan melarangnya melakukan aktivitas apapun kecuali di dalam lingkungan rumah sendiri atau lingkungan perempuan pada umumnya (Muthahhari, 2012). Muslimat yang menutup aurat dengan cadar mempunyai pemahamannya sendiri mengenai cadar. Muslimat yang sudah lama memakai cadar dan paham makna cadar, tidak menjadikan cadar sebagai tren tapi bentuk ketaatan kepada Allah SWT.

Di era media sosial seperti saat ini, keinginan orang untuk tetap aktif dan eksis di media sosial begitu besar, termasuk muslimat bercadar. Media sosial dibutuhkan untuk mencari dan berbagi informasi, penunjang bisnis, penghubung dengan orang banyak, hiburan, dan sebagainya. Munculnya fenomena muslimat cadar juga terlihat di media sosial. Fenomena niqabie selfie semakin banyak di media sosial Facebook dan Instagram, terlihat dari banyaknya foto swafoto akun-akun muslimat memakai cadar. Mereka eksis dengan mengunggah berbagai posting termasuk foto mereka sendiri, baik dengan teman sesama bercadar, maupun dengan keluarga, dan teman dekat. Mereka berfoto memperlihatkan wajah bercadar dengan gaya seperti fotomodel.

Banyak perempuan muslim eksis di media sosial, tidak hanya muslimat bercadar. Tetapi yang paling banyak disorot adalah muslimat bercadar yang eksis di media sosial karena terkadang menimbulkan pro dan kontra. Berbagai komentar bermunculan, baik mendukung maupun menasehati dan mengingatkan mengenai makna cadar. Zulfa \& Junaidi (2018) mengungkapkan, peran media sosial bagi perempuan bercadar saat ini telah menjadi kebutuhan pokok yang disandingkan dengan sandang, pangan, dan papan. Perkembangan digital dan kehidupan perkotaan dengan mobilisasi cepat juga memengaruhi kebutuhan terhadap ponsel pintar yang terhubung dengan internet. Media sosial telah menjadi kehidupan sekunder masyarakat, sebagai wadah untuk melakukan interaksi sosial dengan masyarakat lainnya. Hal tersebut juga berlaku pada muslimat 
bercadar, di balik anggapan selalu menjaga ekskluisivitasnya tetap mengalami terpaan dari pengaruh media sosial dalam kehidupan sehari-hari.

Fenomena ini menjadi pertanyaan besar, mengapa muslimat bercadar yang selama ini dianggap sangat menjaga eksklusivitas cadarnya dalam lingkungan masyarakat, namun di media sosial justru kerap menggunggah potret diri? Pakar media sosial Nukman Luthfi menyatakan bahwa setiap individu baik bercadar ataupun tidak, menggunakan media sosial dengan tujuan bersosialisasi atau melakukan interaksi dengan pengguna lain, maka akan mengalami satu tahapan ketika selalu berusaha untuk memperkenalkan dirinya di depan orang banyak. Hal tersebut menyebabkan, setiap pengguna media sosial akan berusaha memperkenalkan dirinya kepada pengguna lain lewat refleksi diri seperti unggahan potret diri dengan harapan pengguna lain mengenali dirinya. Tahapan selanjutnya, pengguna tersebut tidak lagi berbicara banyak tentang siapa dirinya, namun akan membicarakan lingkungan sekitarnya seperti keluarga, pertemanan, pendidikan, dan lain-lain. Kebanyakan pengguna media sosial terlalu lama berada pada tahap pertama, sehingga terkesan selalu membuat unggahan yang berfokus pada dirinya sendiri (Zulfa \& Junaidi, 2018).

Tidak ada larangan penggunaan media sosial bagi muslimat bercadar. Media sosial merupakan salah satu media untuk memperoleh informasi, serta media untuk berbisnis, serta hiburan, yang setiap individu mempunyai motif dan tujuan dalam penggunaannya. Penelitian ini dilakukan untuk mengungkapkan fenomena komunikasi muslimat bercadar melalui media sosial dengan mengungkapkan: (1) Pengalaman komunikasi muslimat bercadar berkaitan dengan aspek-aspek komunikasi meliputi proses, simbol, dan makna pada media sosial; (2) Konsep diri muslimat bercadar dalam pengunaannya melalui media sosial; dan (3) Motif muslimat bercadar dalam penggunaan media sosial.

Penelitian ini menggunakan teori fenomenologi dan teori interaksi simbolik. Penelitian-penelitian terdahulu yang relevan penelitian ini antara lain Puspanegara (2016) dengan hasil, perilaku komunikasi secara verbal tetap dilakukan oleh wanita bercadar begitu juga dengan komunikasi secara non-verbal. Selain itu komunikasi yang selektif juga diterapkan perempuan bercadar ketika berkomunikasi dengan lawan bicara pria. Hal ini dilakukan untuk membatasi informasi dan pesan yang disampaikan. Penelitian Novri \& Yohana (2016) mengungkap makna cadar oleh wanita bercadar yaitu sebagai perintah agama yang hukumnya boleh dimaknai sebagai hal yang wajib dan juga sunah. Cadar juga dimaknai sebagai kebutuhan, kenyamanan psikologi, dan sebagai pengontrol diri dari segala seuatu yang menjerumuskan ke hal tidak baik.

Selanjutnya, Sari et al. (2014) menemukan adanya kesulitan berkomunikasi terutama menyampaikan pesan akibat ketiadaan petunjuk wajah sebagai alat penting dalam komunikasi non-verbal. Kemudian adanya social judgment yang sering menyebut mereka sebagai ninja dan sulitnya pelayanan publik yang didapat karena kecurigaan dan kesulitan fisik untuk dikenal masyarakat luas. Jamal (2013) menjelaskan konstruksi realitas sosial wanita bercadar memiliki pendapat yang berbeda-beda setiap individu, 
seperti mengkonstruksi dirinya sebagai wanita muslimat, terhormat, serta memotivasi diri sendiri untuk lebih baik. Interaksi sosial wanita bercadar yakni tetap melakukan interaksi dengan masyarakat namun dengan eksistensi yang berbeda. Penelitian mengenai fenomena komunikasi muslimat bercadar dengan pendekatan fenomenologi dan interaksi simbolik belum pernah dilakukan di Kota Pekanbaru. Penelitian ini bertujuan mendeskripsikan fenomena komunikasi muslimat bercadar di Kota Pekanbaru dalam menggunakan media sosial, dengan mengungkapkan mengungkap pengalaman komunikasi, konsep diri, dan motif.

\section{Metode}

Penelitian ini menggunakan jenis penelitian kualitatif deskriptif dengan pendekatan fenomenologi. Data primer dari penelitian ini didapat melalui wawancara mendalam dengan para informan yang terdiri dari 8 informan muslimat bercadar yang memiliki akun-akun media sosial Facebook, Instagram, Whatsapp, dan Line dengan aktivitas sebagai ibu rumah tangga, guru (ustazah), dan karyawan. Data pendukung diperoleh dari hasil observasi peneliti dengan melihat akun media sosial informan serta data sekunder dari buku, jurnal, dan dokumentasi. Penelitian dilaksanakan pada Februari sampai Juli 2019.

Pengolahan data dilakukan menggunakan teknik analisis data Miles dan Hubberman, dengan unit analisisnya meliputi; pengumpulan data, reduksi data, penyajian data, dan verifikasi/ penarikan kesimpulan. Teknik pemeriksaan keabsahan data atau validitas data menggunakan teknik validasi dengan memanfaatkan jenis triangulasi sumber. Triangulasi sumber berarti membandingkan, memeriksa ulang derajat kepercayaan suatu informasi yang diperoleh melalui sumber berbeda.

\section{Hasil dan Pembahasan}

\section{Penggunaan Media Sosial oleh Muslimat Bercadar}

Penggunaan media sosial oleh muslimat bercadar terlihat pada Facebook informan MR. Tahun 2011 MR mengirim dan membagikan pesan kajian-kajian agama, status kutipan (quote) Al-Qur'an, hadis riwayat, gambar pemandangan, dan aktivitas lain seperti mengganti foto profil, juga beberapa kiriman yang ditandai oleh orang lain atau teman-temannya, dan kiriman pengingat diri. Namun pada laman profil MR lebih banyak terdapat kiriman yang ditandai. Tahun 2012, MR mulai terlihat mengirim konten usaha jahitnya. Tahun 2013, MR membuat kiriman kajian-kajian agama, status pemikiran, promosi bisnis jahit, serta aktivitas pergantian foto profil. Terlihat juga kiriman MR mengenai cadar. Tahun 2014 kiriman MR lebih banyak konten bisnis jahitnya saja. Tahun 2015 terlihat kiriman MR mengenai cadar. Pada tahun 2016 sampai 2019, kiriman mengenai resep masakan, kajian-kajian ustaz, promosi bisnisnya, jadwal kajian, dan lainnya juga terlihat dalam Facebook MR. Perkembangan kiriman MR di akun Facebook dapat dilihat pada gambar berikut: 


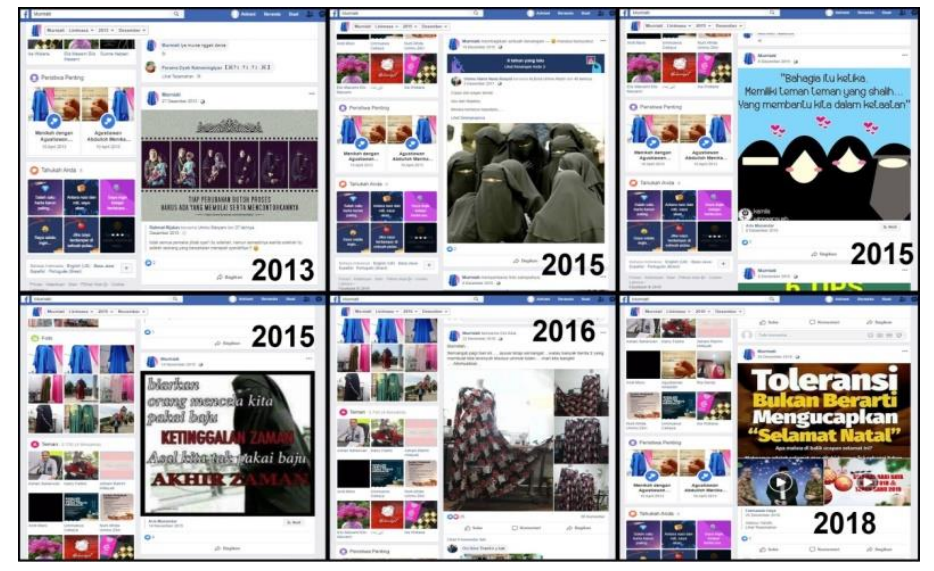

Sumber: Hasil penelitian

Gambar 1. Penggunaan Facebook oleh MR

Informan RS menggunakan aplikasi WhatsApp untuk memberikan informasi mengenai jadwal pengajian. WhatsApp RS dalam postingan status story lebih sering berbagi kutipan-kutipan tentang agama, kajian, dan jadwal kajian. Kutipan seperti ajakan untuk melakukan salat duha dengan memasukkan kutipan H.R. Tarmidzi, juga terlihat pada kiriman WhatsApp RS. Pada WhatsApp story RS mengirim waktu dan jadwal bagi yang berminat untuk mengikuti tahsin serta kajian-kajian lainnya.

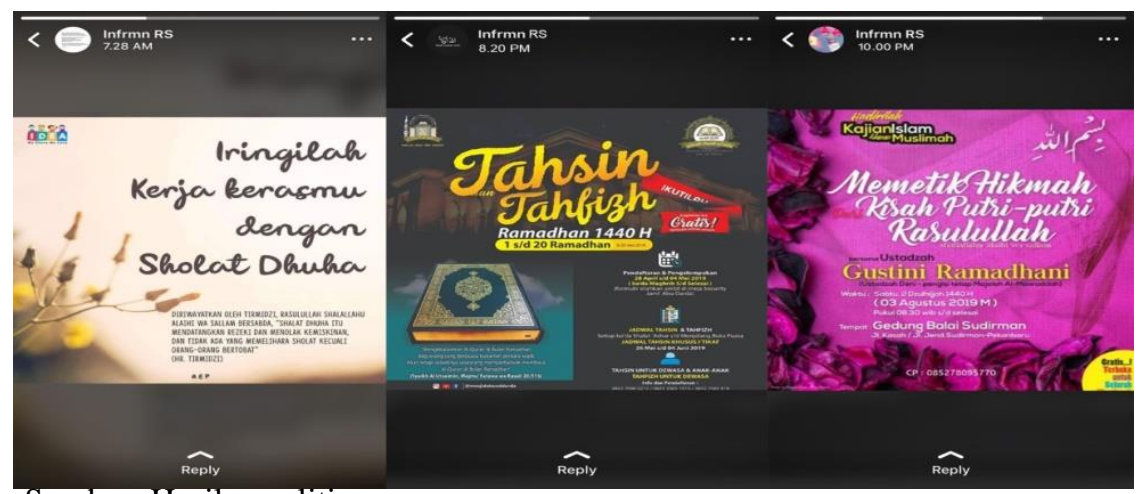

Sumber: Hasil penelitian

Gambar 2. Penggunaan WhatsApp oleh RS

Penggunaan media sosial Instagram terlihat pada akun informan RA. Instagram RA yang aktif tahun 2013 sampai 2019 berisi kiriman keseharian seperti makanan, acara ulang tahun, kutipan dengan keterangan imbauan, lokasi tempat berada, jadwal kajian, dan lain-lain dengan memberi keterangan pada kirimannya. RA juga aktif mempromosikan bisnis online dengan kiriman baju-baju gamis di Instagram, foto RA bersama dengan keluarga, kerabat, dan teman-teman pengajian dengan keteranganketerangan RA yang senang bisa berkumpul dan bertemu. Penggunaan WhatsApp story, informan RA hanya mengirim bisnis penjualan gamisnya. Sedangkan pada penggunaan Line, RA bergabung dengan grup bisnis usaha beranggotakan pelaku usaha yang sama 
dari daerah lainnya. Penggunaan Line bagi RA, juga untuk dapat berkomunikasi dengan keponakan-keponakannya yang lebih aktif di media sosial Messenger Line tersebut.

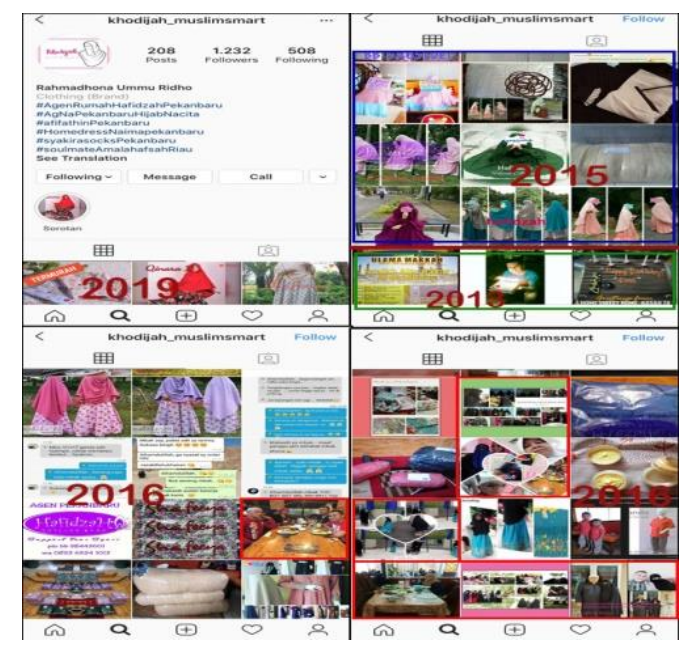

Sumber: Hasil penelitian

Gambar 3. Penggunaan Instagram oleh RA tahun 2013-2019

Penggunaan Messenger Line oleh informan NS terlihat pada kiriman sebagai berikut:

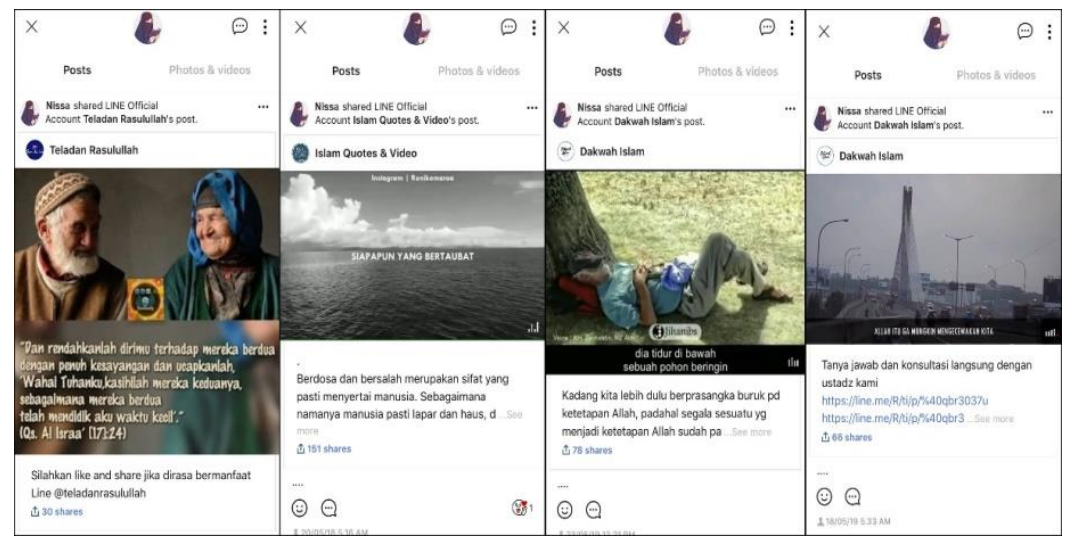

Sumber: Hasil penelitian

Gambar 4. Penggunaan Messenger Line Oleh NS

Pada Messenger Line terlihat juga beberapa kiriman NS yang membagi kutipankutipan bijak mengenai agama dari akun-akun dakwah seperti berbagi kajian, kutipan, dakwah ustaz, dan lainnya yang berkaitan tentang agama Islam, penyemangat, serta pengingat diri dalam ketaatan kepada Allah. NS yang aktif menggunakan Messenger Line sejak 2017 membagi banyak kiriman dari akun-akun dakwah tersebut.

\section{Pengalaman Komunikasi Muslimat Bercadar di Media Sosial}

Pengalaman-pengalaman yang langsung dialami para informan memberikan suatu gambaran tentang pengevaluasian nilai diri sebagai pengguna media sosial. Suatu 
peristiwa yang mengandung unsur komunikasi akan menjadi pengalaman komunikasi tersendiri bagi individu, dan pengalaman komunikasi yang dianggap penting akan menjadi pengalaman yang paling diingat dan memiliki dampak khusus bagi individu tersebut (Hafiar, 2012). Wirman (2016) mengatakan, pengalaman komunikasi merupakan suatu yang dialami individu dan berkaitan dengan aspek-aspek komunikasi, meliputi proses, simbol, ataupun makna yang dihasilkan serta dorongannya pada tindakan. Pengalaman terhubung pada sebuah fenomena dan dapat merujuk pada suatu peristiwa. Peristiwa komunikasi yang dilakukan muslimat bercadar di media sosial pada penelitian ini dapat digambarkan sebagai suatu pengalaman komunikasi bagian dari kesadaran dalam melakukan interaksi dengan pengguna media sosial lainnya. Berikut digambarkan dengan model yang peneliti temukan di lapangan :

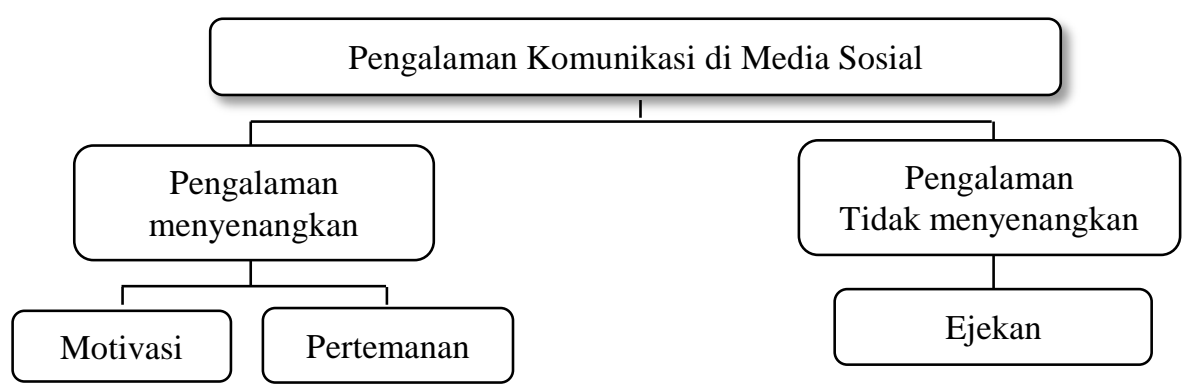

Sumber : Olahan Penulis

Gambar 5. Model Pengalaman Komunikasi

Berkaitan dengan penelitian ini, pengalaman komunikasi yang dialami muslimat bercadar dikategorikan menjadi pengalaman terbaik dan pengalaman tidak menyenangkan. Pengalaman terbaik berupa motivasi dan pertemanan, sedangkan pengalaman tidak menyenangkan berupa diskriminasi dan ejekan atau hinaan. Sebagian besar informan memiliki pengalaman yang tidak jauh berbeda. Karakter hubungan dalam pengalaman komunikasi yang menyenangkan dapat dilihat dari sejauh mana hubungan yang dialami dalam komunikasi muslimat bercadar dengan para pengguna media sosial lainnya. Motivasi dan pertemanan yang mereka dapati di media sosial sebagai pengalaman yang terbaik meningkatkan kemajuan dan hubungan yang positif. Sedangkan diskriminasi dan ejekan yang dialami sebagai pengalaman tidak menyenangkan, memunculkan perasaan kekecewan karena sikap dan pandangan yang tidak seharusnya mereka dapatkan.

\section{Pengalaman Terbaik}

Orang melakukan perbuatan tidak menyenangkan di media sosial baik perkataan, tindakan, dan lainnya. Karena di tengah kecanggihan teknologi dari arus globalisasi ini, kaum milenial justru memanfaatkan hal tersebut sebagai sarana memenuhi kebebasan, kepuasan, serta kesenangan. Muslimat bercadar dalam menggunakan media sosial juga memiliki pengalaman saat menjelajah ke dunia virtual. Dari pengalaman yang diungkapkan oleh muslimat bercadar, menunjukkan penerimaan, pertemanan, dan 
motivasi informan dalam penggunaan media sosial dengan penampilan mereka serba tertutup untuk melindungi aurat merupakan pengalaman terbaik. Tampilan mereka yang bercadar yang juga tidak selalu ditonjolkan di media sosial tidak membuat mereka memiliki pandangan negatif dengan pengalaman yang dialami dengan bercadar. Seperti pengalaman menyenangkan muslimat bercadar yang dapat mengikuti grup-grup pengajian serta dapat menjalin silahturahmi yang baru dengan tetap bisa menjaga ukhuwah baik.

"Senengnya karena kakak yang mulai bercadar terus mengikuti pengajian jadi ada ikut gabung dengan grup-grup pengajian kakak di WhatsApp. Di situ kakak ya alhamdulillah dapat mengenal teman-teman lainnya." (ST, September 2019).

"Pengalaman terbaik kakak ya bisa ikut dalam grup-grup pengajian. Walaupun kakak enggak ada komen-komen, karena sebenarnya juga cuma adminnya yang bisa kirim posting-an ke grup, info-info, jadwal kajian. Jadi di sana kita bisa baca-baca, kita bisa tahu. Enggak untuk yang bercadar aja (grup), cuma ya pas kakak memutuskan untuk bercadar, di situlah keingintahuan kakak untuk dapat pengetahuan agama lebih jauh lagi.” (MA, September 2019).

Pengalaman terbaik muslimat bercadar dalam penggunaan media sosial yaitu motivasi dan pertemanan yang mereka peroleh. Motivasi dan pertemanan yang diterima dari dunia virtual dapat berlanjut ke dunia sebenarnya (real life) yang membantu mereka untuk tidak dibedakan karena penampilan mereka. Pada peristiwa ini, keberadaan muslimat bercadar yang identitasnya dipahami sebagai perempuan yang fanatik dengan agama diterima dengan positif, sehingga pandangan dan sikap aneh terhadap mereka tidak lagi dirasakan. Sikap positif dari lingkungan pengguna media sosial menunjukkan kesedian untuk menjalin pertemanan.

Bertemu dengan orang-orang baru di media sosial untuk menambah akses pertemanan yang lebih luas di dunia virtual dan dunia sebenarnya, juga menjadi pengalaman terbaik muslimat bercadar dalam menggunakan akun-akun media sosial. Selain itu, kemudahan yang disediakan media sosial membuka ruang bagi muslimat bercadar untuk memperoleh pengetahuan kajian agama Islam, tentang anak, pendidikan serta menjalin ukhuwah dengan individu lainnya.

Mitra (dalam Talani, 2014) mengungkapkan, sebagai makhluk sosial, manusia butuh berinteraksi dengan orang lain. Melalui interaksi manusia dapat berhubungan, berkolaborasi, dan menunjukkan eksistensi dirinya dalam ruang sosial yang melingkupinya. Media sosial mampu memenuhi kebutuhan itu, di mana seseorang dapat berinteraksi dengan orang lain tanpa dibatasi ruang dan waktu. Merujuk pada Mitra, situs jejaring sosial seperti Facebook, Instagram, WhatsApp, Line, dan lainnya telah menjadi fenomena sosial, memperkenankan orang-orang terhubung dan membangun hubungan jarak jauh dengan teman dan kolega. 
Kemudahan yang diberikan media digital dengan fitur media sosialnya juga mempengaruhi ranah agama dan memberikan pengalaman terbaik bagi penggunanya. Perkembangan media komunikasi memberi pengaruh besar bagi perkembangan aktivitas dakwah islamiyah. Sebelum ada media sosial, muslimat harus ke masjid apabila ingin mendapatkan pengetahuan keagamaan, seperti mengikuti pengajian dan majelis taklim. Dengan adanya media sosial yang menampilkan pesan-pesan dakwah, khalayak bisa memperoleh pengetahuan keagamaan melalui media, tanpa harus ke masjid atau pengajian. Ini merupakan hal yang cukup menguntungkan bagi muslimat yang tetap ingin memperdalam pemahaman pengetahuan agamanya atau hanya ingin mendapatkan siraman rohani, namun memiliki aktivitas yang sangat padat.

\section{Pengalaman Tidak Menyenangkan}

Pengalaman komunikasi di media sosial yang tidak menyenangkan juga dialami muslimat bercadar, bahkan ungkapan-ungkapan yang tidak seharusnya dituturkan juga dialami beberapa informan. Komentar-komentar miring yang didapat muslimat bercadar saat menggunakan media sosial antara lain dianggap seperti teroris, ninja, aneh, dan lainnya. Hal ini menimbulkan diskriminasi dan perasaan tidak menyenangkan, yang dinilai sebagai intimidasi terhadap perempuan bercadar. Tiga informan mengungkapkan dirinya memiliki pengalaman tidak menyenangkan.

"Pernah ada upload foto NS kak di akun Facebook. Jadi ada yang komen "teroris". NS yang enggak pernah dapat komen yang kayak gitu, agak kaget. Terus NS hapus aja. Nggak enak juga dapat komen kayak gitu kan kak. Kadang ada NS upload (foto) lagi terus NS hapus lagi. Terus kadang mikir juga kalau mau upload. Kalau dari perasaan NS, ada perasaan bener juga, ngoreksi diri sendiri gitulah.” (NS, Juli 2019).

Pengalaman tidak menyenangkan dapat membuat seseorang melihat dirinya secara negatif. Namun informan yang memiliki pengalaman tidak menyenangkan tidak menjadikan pengalaman tersebut sebagai faktor yang dapat menurunkan kepercayaan diri. Mereka berusaha melihat pengalaman tersebut dengan pandangan positif.

Pengalaman komunikasi yang tidak menyenangkan dapat dikatakan sebagai peristiwa komunikasi yang isi, konteks, dan dampak dari proses komunikasi tersebut dirasa dan dipahami sebagai sesuatu yang bersifat melemahkan rasa percaya diri atau self esteem (Wirman, 2016). Komunikasi dengan cara penyampaian yang tidak efektif serta unsur pesan negatif (ejekan, hinaan, dan lain-lain) dapat menimbulkan perasaan tidak menyenangkan.

Peristiwa pengalaman komunikasi tidak menyenangkan bagi muslimat bercadar yang merupakan hasil dari interaksi yang terjadi di media sosial memiliki pengaruh. Namun pengaruh yang ditimbulkan tersebut tidak melemahkan pelaku dengan pemahaman yang mereka yakini, yang merupakan pelemahan sesaat. Mereka tetap terus memunculkan pemikiran yang positif dengan self defence mechanism dengan 
melakukan interpolasi terhadap pengalaman komunikasi tidak menyenangkan tersebut, seperti dibahas Wirman (2016).

Selain itu anggapan dan pandangan yang tertuju kepada muslimat bercadar sebagai teroris adalah pandangan yang tidak dapat diterima. Artinya, mereka yang paham mengenai agama akan berperilaku sesuai dengan ajaran yang diperintahkan oleh Allah dan Rasulullah. Mereka menentang terorisme sebagai aksi jihad. Bagi mereka stigma negatif terhadap muslimat bercadar dapat dikatakan konstruksi media.

Penelitian Iskandar (2013) mengungkap, tidak semua perempuan bercadar hidup tertutup dan tidak mau bergaul dengan lingkungan masyarakat. Adanya stigma negatif masyarakat terhadap muslimat bercadar memang dirasakan oleh muslimat bercadar seperti bagian dari teroris, kelompok aliran keras dan kelompok ekslusif, menutup diri dan tidak mau bergaul dengan lingkungan. Namun bagi muslimat bercadar, tidak semua masyarakat berprasangka negatif terhadap diri mereka. Sebagian masyarakat juga memiliki pemahaman yang sama dengan mereka sehingga tidak berprasangka negatif. Dalam melakukan hal-hal yang bersifat positif agar mendapat citra dan pandangan positif dalam masyarakat, muslimat bercadar melakukan upaya-upaya seperti bersilaturahmi dan berhubungan baik dengan masyarakat, serta tidak mengeksklusifkan diri mereka. Dengan cara seperti itu masyarakat akan memahamai muslimat bercadar sama halnya dengan masyarakat lainnya.

Muslimat bercadar dengan pandangan yang mereka dapatkan mencoba menerima keadaan mereka yang dianggap sebagai bagian dari terorisme. Namun mereka mencoba melawan pandangan masyarakat itu dengan melakukan hal-hal serta sikap perilaku yang positif sehingga masyarakat akan menilai mereka dengan pandangan yang positif. Dalam bermasyarakat, muslimat bercadar juga mengikuti aturan dan tradisi lingkungannya sesuai dengan syariat Islam, seperti menjalin silaturahmi, dan menerima pendapat orang lain terhadap mereka. Hal tersebut merupakan salah satu upaya untuk mewujudkan pandangan terhadap diri mereka sebagai muslimat bercadar yang tidak mengeksklusifkan diri dan ikut berbaur dengan masyarakat.

Pengguna media sosial sebagai digital native tetap dapat melakukan refleksi diri pada pentingnya memperhatikan sebuah privasi, setelah mendapatkan pengalamanpengalaman tidak menyenangkan dalam penggunaan media sosial. Pengalaman terbaik dan tidak menyenangkan pengguna media sosial dapat meningkatkan kesadaran tentang kemandirian, harga diri, dan kreativitas serta bijaksana dalam memilah informasi.

Dari hasil penelitian tentang pengalaman terbaik dan pengalaman tidak menyenangkan muslimat bercadar dalam penggunaannya terhadap media sosial dilihat pada tabel berikut : 
Tabel 1. Hasil Observasi Penggunaan Media Sosial oleh Muslimat Bercadar

\begin{tabular}{|c|c|c|}
\hline Informan & Pengalaman Terbaik & $\begin{array}{l}\text { Pengalaman Tidak } \\
\text { Menyenangkan }\end{array}$ \\
\hline$\overline{\mathrm{RA}}$ & $\begin{array}{l}\text { Orang yang menjaga tutur kata dan } \\
\text { sopan, orang yang menghargai mereka } \\
\text { sebagai muslimat bercadar di media } \\
\text { sosial }\end{array}$ & $\begin{array}{l}\text { Pernah mendapat pesan di } \\
\text { Facebook untuk tidak terlalu } \\
\text { lebay (berlebihan) }\end{array}$ \\
\hline $\mathrm{RS}$ & $\begin{array}{l}\text { - Orang sopan dan berkomunikasi yang } \\
\text { baik dengan RS } \\
\text { - Bisa menyampaikan informasi kajian } \\
\text { langsung ke banyak penerima }\end{array}$ & Tidak Ada \\
\hline $\mathrm{RN}$ & $\begin{array}{l}\text { Bisa mengenal banyak orang di grup } \\
\text { pengajian }\end{array}$ & Tidak Ada \\
\hline ST & $\begin{array}{l}\text { - Dapat mengikuti pangajian yang ada di } \\
\text { grup media sosial }\end{array}$ & Tidak Ada \\
\hline MR & $\begin{array}{l}\text { - Dapat ilmu dari grup pengajian di } \\
\text { media sosial }\end{array}$ & Tidak Ada \\
\hline MA & $\begin{array}{l}\text { - Dapat ilmu dari grup pengajian di } \\
\text { media sosial }\end{array}$ & Tidak Ada \\
\hline NS & $\begin{array}{l}\text { - Karena dengan mulai bercadar dapat } \\
\text { mengenal teman-teman di pondokan } \\
\text { yang juga bercadar dan dapat } \\
\text { berdiskusi di grup-grup media sosial } \\
\text { bersama ustadzah }\end{array}$ & $\begin{array}{l}\text { Pernah dikomentari teroris } \\
\text { dengan orang yang tidak } \\
\text { dikenal di media sosial }\end{array}$ \\
\hline WD & $\begin{array}{l}\text { Dapat bertemu dengan teman-teman } \\
\text { baru yang dapat bersama membagi } \\
\text { kajian }\end{array}$ & $\begin{array}{l}\text { Pernah dikatakan ninja dan } \\
\text { dibilang aneh di media sosial }\end{array}$ \\
\hline
\end{tabular}

\section{Konsep Diri}

Faktor pembentukan konsep diri muslimat bercadar di media sosial yaitu sikap dan pandangan reference group, pandangan diri secara psikis, dan pandangan diri secara sosial. Di media sosial hal ini merupakan dunia virtual dan manusia tidak menghabiskan waktu seluruh kehidupannya pada perangkat tersebut.

\section{Sikap dan Pandangan Significant Other}

Karakter setiap individu berbeda-beda, hal ini juga dipengaruhi oleh orang-orang di lingkungannya terutama yang paling dekat dengan individu tersebut. Mereka adalah keluarga, orang tua, saudara, kerabat, teman, sahabat, orang lain, serta lingkungan masyarakat yang mempunyai ikatan emosional dan perlahan-lahan membentuk konsep diri. Sikap dan pandangan significant others terhadap informan turut membentuk konsep diri mereka. Keluarga memiliki pengaruh dan peranan yang besar terhadap tingkah laku anggotanya karena lingkungan keluarga merupakan pendidikan utama dan pertama bagi anggotanya. Pendidikan dalam sebuah keluarga akan terwujud dengan baik dengan adanya pergaulan dan hubungan saling mempengaruhi cara timbal balik antara orang tua dan anak. Suasana keluarga dengan kebiasaan dan sikap perbuatan 
terpuji dan menghindarkan perbuatan yang tercela akan mewujudkan anggota keluarga tumbuh dan berkembang dengan wajar dan tercipta keserasian dalam suatu keluarga. Sehingga, pengaruh keluarga akan membekas bukan hanya pada pribadi keluarga tetapi juga sikap perilaku keagamaan dari anggota keluarga.

Sikap pribadi dan pandangan diri juga dapat berkembang dalam ruang lingkup pola sosial-religius. Untuk memperoleh kerangka dasar tersebut, sikap dan pandangan manusia mengalami perkembangan yang berada dalam proses belajar secara individual dan secara sosial. Ini dapat menyebabkan terjadinya suatu perpaduan dalam rangka pembentukan pribadi manusia sebagai anggota masyarakat atau kelompok. Jika pada awalnya alasan memakai cadar diragukan orang tua, saudara, kerabat, sahabat, dan lingkungan, namun bertahap penerimaan berlangsung positif.

"Kakak mulai bercadar karena lihat lingkungan, lingkungan belum ada yang bercadar. Terus kakak ikut pengajian, mulai-mulailah kakak meniatkan diri dengan bercadar. Suami kakak mendukung, kalau di keluarga enggak juga. Biasa kadang di lingkungan keluarga masih... ya kadang mereka nerima juga, waktu pertama-pertama mungkin susahlah.” (RS, April 2019).

Ada informan yang mendapat dukungan penuh dari pihak keluarga seperti ayah, ibu, dan saudara. Walaupun dalam keluarga besar penerimaan dengan hijab bercadar belum diterima seutuhnya.

"NS orang tua yang nyuruh awal kak, mereka masukkan NS ke sekolah pesantren. Tapi NS mau juga, sambil belajar-belajar. Sampai sekarang NS pakai cadar.” (NS, April 2019)

Lingkungan sekolah atau kampus juga merupakan suatu lembaga resmi yang di dalamnya terdapat pengajaran dan pendidikan formal dengan program yang sistematik. Sehingga dapat memberikan bimbingan pengajaran dan latihan kepada siswa untuk dapat berkembang dengan optimal sesuai dengan potensi mereka, baik secara psikis (intelektual dan emosional), fisik, sosial, maupun moral spiritual. Begitu juga dengan media, termasuk faktor yang dapat mempengaruhi perubahan perilaku dan pandangan seseorang. Media-media komunikasi yang disampaikan berkenaan dengan hal agama, maka perubahan perilaku yang muncul juga dapat terjadi perubahan perilaku keagamaannya.

\section{Sikap dan Pandangan General Other}

Kelompok masyarakat dalam konteks ini adalah pengguna media sosial yang aktif di dunia virtual. Pertemanan di media sosial baik teman yang berada di kehidupan nyata, teman pengajian, teman yang ditemui di dunia virtual, serta sekelompok pengguna media sosial, membuat mereka saling berbagi informasi. Sikap positif yang 
mereka terima di dunia virtual tersebut tidak membuat mereka memiliki pikiran terasing.

\begin{abstract}
"Awalnya mereka mungkin kaget ya, karena kapan ya.. waktu itu kan cadar masih jarang banget, satu-satu, udah 11 tahun kakak bercadar. Jadi mereka yang "eh MR bercadar? kenapa? kenapa?" dari teman-teman ditanyain gitu, dari keluarga jauh juga karena lama enggak ketemu kan. Walaupun sempat juga tuh dulu bilangin kakak ikut aliran apa, gitu kan. Tapi ya kelamaan mereka udah biasa aja, karena bercadarkan niatnya kakak, keputusan kakak jadi mereka ya menghargai aja. Kakak juga dulu ada posting foto-foto kan tapi udah kakak hapus, jadi mereka tau dari posting-an kakak itu (MR bercadar). Apalagi sekarang perempuan yang bercadar udah banyak, di media sosial juga. Jadi udah biasa aja, kan. Walaupun ada muncul stigmastigma negatif yang bilangin teroris”. (MR, Oktober 2019).
\end{abstract}

Pengguna media sosial lainnya memberikan sikap dan pandangan positif yang menerima adanya pemahaman agama mengenai cadar. Walaupun orang-orang yang berada di dunia virtual tersebut, juga merupakan teman dan lingkungan yang dekat dengan informan, namun penerimaan positif dan negatif juga tetap terjadi.

\title{
Makna Cadar Bagi Muslimat Bercadar
}

Cadar dipandang sebagai hal positif karena niat untuk beribadah kepada Allah. Penampilan yang menutup aurat seluruh tubuh hingga sebagian wajah tidak mereka interpretasi sebagai sesuatu hal yang negatif. Walaupun ada masyarakat yang memandang mereka dengan stigma-stigma negatif, namun mereka tetap menguatkan niat untuk beribadah,
"Kakak sih ya cadar kan insya Allah dapat melindungi diri kita, untuk pengingat diri kita, mengontrol untuk menghindari hal-hal yang dilarang Allah. Jadi apa yang kita lakukan dengan bercadar bagaimana kita untuk mengingat Allah. Jadi kita terus belajar, niatnya kan untuk takwa, beribadah kepada Allah.” (MR, Maret 2019).
"Kalau cadar ini WD untuk mengurangi pandangan dari lawan jenis gitu kak. Kadang kan kita merasa enggak nyaman dilihatin lawan jenis, jadi kalau pakai cadar insya Allah merasa terlindungi, jadi lebih nyaman aja pakai cadar" (WD, April 2019).

Cadar juga dimaknai sebagai pengontrol diri dari hal-hal yang dilarang, mengurangi pandangan orang yang melihat yang akan menjadi sebuah fitnah, melindungi diri, dan pengingat untuk selalu bertakwa kepada Allah. Pandangan positif mengenai cadar bagi muslimat bercadar menunjukkan niat mereka dalam beribadah. 


\section{Pandangan Diri Secara Psikis di Media Sosial}

Pandangan psikis muslimat bercadar di media sosial memiliki karakter berbeda yang membentuk konsep diri positif dan negatif. Perspektif informan memandang diri sendiri dari interaksi yang dilakukan atas persepsi dan interpretasi informan secara psikis.

"Namanya kita sebagai orang kan harus ramah, apalagi bercadar kesannya tuh orang kan pada anggapnya ramah, baik. Yaa, iya.. tergantung pribadi masing-masing juga. Kakak sih sebisa mungkin harus ramah lah, sesama manusia harus saling ramah.” (RA, Februari 2019).

"Ramah mungkin kak ya, karena kan biasanya orang lain yang menilai. Tapi NS sih baik-baik aja sih. Maksudnya berhubungan dengan teman-teman yang lain, dengan yang baru kenal di media sosial juga ada. Kalau ada orang nanya atau teman nanya di media sosial ajak ngobrol NS gitu kan, ya NS terbuka aja sih. Tapi biasanya yang perempuan aja, kalau laki-laki mungkin dibatasi soalnya ada batasan. Kalau ada kajian yang di-share di medsos kan itu NS suka nge-tag teman, biar ilmunya sama tahu-tahu, sama-sama memahami. Kadang teman tuh, dia senang ngobrol sama NS." (NS, April 2019).

Pelaku yang melihat diri secara terbuka membentuk karakter yang ramah dan tidak menutup diri walaupun dengan memakai cadar, namun sikap untuk menerima orang lain juga tidak dihindarkan. Pandangan diri secara psikis dengan membentuk karakter yang tertutup juga didapat dari para pelaku karena tidak ingin menonjalkan diri di suatu kelompok atau di tengah-tengah masyarakat.

"Kakak enggak ada buat-buat status, paling share tentang masakan. Kalau komen-komen di tempat orang yang share masakan itu kan, terus kalau di kajian enggak sering juga, sesekali. Kakak enggak inilah, apa ya, kesannya kayak tertutup. Karena kakak emang enggak banyak ini, enggak banyak interaksi di media sosial." (RN, April 2019).

\section{Pandangan Diri Secara Sosial}

Pandangan diri secara sosial yaitu interaksi informan dengan para pengguna akun lainnya di media sosial. Perspektif sosial orang lain memandang informan dari interaksi yang dilakukan atas persepsi dan interpretasi informan secara sosial. Informan dalam penelitian ini mempersepsi pandangan orang lain dengan interaksi sosial diri sendiri, beberapa menyatakan karakter yang ramah dan menyenangkan.

"Sepertinya kakak ini ramah ya. Kakak enggak tahu juga sih, karena kakak kan selalu mengingatkan untuk kebaikan, untuk akhirat. Karena apa-apa kan suka kakak tegur dan ya alhamdulillah ya itu tadi kakak bilang mereka nggak marah, kadang "oh iya, terima kasih ya sudah diingatkan". Jadi berpikir positif aja, kita memberi kebaikan untuk orang. Kalau buat status 
biasanya kakak manfaat untuk akhiratlah, ilmu-ilmu, mengajak, berinfak, segala macamlah yang khusus akhiratlah.” (ST, April 2019).

Tertutup dan tidak banyak interaksi di media sosial juga dipersepsi informan dalam mempersepsi dirinya sendiri, dalam pandangan sosial dan penggunaannya di media sosial.

"Mungkin kalau teman-teman di Facebook yang enggak tahu kakak, kayak kita kenalnya di media sosial itu mungkin dipikirnya kakak agak tertutup karena kan cuma sekali-sekali komen di tempat posting-an kajian-kajian sama masakan dan kakak juga enggak, enggak ada buat-buat status. Paling quote-quote, tentang kajian di foto profil kakak yang di Facebook, ada juga mungkin yang lihatnya kakak nih sombong, karena nggak terlalu berbaur, gitu kan.” (RN, April 2019).

Konsep diri yang terbentuk dari persepsi terhadap dirinya sendiri, persepsi orang lain terhadap dirinya serta perasaan bangga atau kecewa yang dialami di hadapan individu lain akan mempengaruhi pola-pola interaksi individu dengan orang lain. Konsep diri sangat erat kaitannya dengan proses hubungan interpersonal yang vital bagi perkembangan kepribadian. Konsep diri tidak hanya berkenaan dengan masalah psikologis, namun juga berhubungan dengan komunikasi yang mana hubungan akan terjalin dengan komunikasi dan interaksi. Faktor-faktor yang mempengaruhi dalam penemuan penelitian ini yang membentuk konsep diri para informan dapat dilihat pada tabel berikut:

Tabel 2. Tipe Konsep Diri Muslimat Bercadar di Media Sosial

\begin{tabular}{|c|c|c|c|c|c|}
\hline Informan & $\begin{array}{l}\text { Significant } \\
\text { Other }\end{array}$ & $\begin{array}{l}\text { General } \\
\text { Other }\end{array}$ & $\begin{array}{l}\text { Pandangan Diri } \\
\text { Tentang Cadar }\end{array}$ & $\begin{array}{l}\text { Pandangan } \\
\text { Secara Psikis }\end{array}$ & $\begin{array}{l}\text { Pandangan } \\
\text { Secara Sosial } \\
\end{array}$ \\
\hline RA & Positif & $\begin{array}{l}\text { Biasa } \\
\text { saja }\end{array}$ & $\begin{array}{l}\text { Sunah, dapat } \\
\text { melindungi diri dan } \\
\text { sebagai pengontrol } \\
\text { diri }\end{array}$ & Ramah & $\begin{array}{l}\text { Ramah, } \\
\text { bersosialisasi }\end{array}$ \\
\hline $\mathrm{RN}$ & Positif & Positif & $\begin{array}{l}\text { Untuk } \\
\text { menghilangkan } \\
\text { fitnah dan syahwat } \\
\text { dari laki-laki }\end{array}$ & Tertutup & $\begin{array}{l}\text { Tidak banyak } \\
\text { berkomunikasi }\end{array}$ \\
\hline MR & Positif & $\begin{array}{l}\text { Negatif, } \\
\text { Positif }\end{array}$ & $\begin{array}{l}\text { Untuk melindungi } \\
\text { diri dari hal-hal } \\
\text { yang dilarang dan } \\
\text { sebagai pengontrol } \\
\text { diri }\end{array}$ & Ramah, tegas & Ramah, pamer \\
\hline RS & Positif & Positif & $\begin{array}{l}\text { Melindungi diri, } \\
\text { sebagai pengontrol } \\
\text { diri, pengukur diri } \\
\text { untuk lebih baik } \\
\text { lagi }\end{array}$ & $\begin{array}{l}\text { Murah dalam } \\
\text { memberi ilmu }\end{array}$ & Beribawa \\
\hline
\end{tabular}




\begin{tabular}{|c|c|c|c|c|c|}
\hline Informan & $\begin{array}{l}\text { Significant } \\
\text { Other }\end{array}$ & $\begin{array}{l}\text { General } \\
\text { Other }\end{array}$ & $\begin{array}{l}\text { Pandangan Diri } \\
\text { Tentang Cadar }\end{array}$ & $\begin{array}{l}\text { Pandangan } \\
\text { Secara Psikis }\end{array}$ & $\begin{array}{l}\text { Pandangan } \\
\text { Secara Sosial }\end{array}$ \\
\hline MA & Positif & Positif & $\begin{array}{l}\text { Sebagai pengontrol } \\
\text { diri untuk dapat } \\
\text { menjadi muslim } \\
\text { yang disunnahkan }\end{array}$ & Pendiam & $\begin{array}{l}\text { Tidak suka } \\
\text { mencampuri } \\
\text { urusan orang } \\
\text { lain yang dapat } \\
\text { menyebabkan } \\
\text { miskomunikasi }\end{array}$ \\
\hline WD & Positif & Negatif & $\begin{array}{l}\text { Untuk megurangi } \\
\text { pandangan buruk, } \\
\text { untuk mengurangi } \\
\text { pandangan negatif }\end{array}$ & $\begin{array}{l}\text { Terbuka, } \\
\text { ramah, } \\
\text { bersemangat }\end{array}$ & $\begin{array}{l}\text { Ramah, } \\
\text { bersosialisasi }\end{array}$ \\
\hline NS & Positif & Negatif & $\begin{array}{l}\text { Untuk melindungi } \\
\text { diri dari pandangan } \\
\text { lawan jenis dan } \\
\text { kenyamanan } \\
\text { berpakaian }\end{array}$ & $\begin{array}{l}\text { Ramah, } \\
\text { terbuka }\end{array}$ & $\begin{array}{l}\text { Menyenangkan, } \\
\text { pamer }\end{array}$ \\
\hline ST & Positif & Positif & $\begin{array}{l}\text { Sunah, untuk dapat } \\
\text { menjaga perilaku } \\
\text { dan sikap, untuk } \\
\text { menjadi lebih baik } \\
\text { lagi }\end{array}$ & Peduli, ramah & Ramah, peduli \\
\hline
\end{tabular}

Sumber : Hasil Penelitian

Cooley menyebutkan konsep diri sebagai the looking glass-self, yang secara signifikan ditentukan oleh apa yang seseorang pikirkan mengenai pikiran orang lain terhadapnya, jadi menekankan pentingnya respons orang lain yang diinterpretasikan secara subjektif sebagai sumber primer data mengenai diri. Artinya individu akan membayangkan dirinya sebagai individu lain di dalam benaknya dengan melakukan penilaian dari: (1) Bagaimana dirinya tampil di hadapan individu lain, (2) individu membayangkan bagaimana ia dinilai oleh individu lain, dan (3) bagaimana individu mengalamai perasaan bangga atau kecewa di hadapan individu lain (Mulyana, 2004).

Konsep diri setiap individu dapat didasarkan dari keseluruhan pengetahuan daftar julukan dirinya yang menempatkan ke dalam kelompok atau kategori-kategori sosial tertentu. Begitu halnya dengan muslimat bercadar yang berada di luar lingkungan (kelompok atau kategori sosialnya), jika dikatakan muslimat memakai cadar yang menutup seluruh tubuh serta sebagian wajah, jika pada sebuah pengajian mereka adalah sama-sama orang yang belajar ilmu agama. Walaupun lingkungan luar ada yang menjuluki mereka dengan ninja, sampai hal yang tidak menyenangkan yaitu teroris, mereka yang melihat tentang diri mereka dengan cadar adalah mereka yang memandang diri mereka secara positif. Mereka tidak memaknai diri mereka memakai cadar adalah negatif yang mana mereka takut dengan cadar dan pandangan orang-orang dengan stigma-stigma negatif.

Calhoun \& Acocella mengelompokkan konsep diri dalam dua jenis yang berbeda, yaitu: a) Konsep-Diri Positif, konsep diri ini lebih mengarah kepada penerimaan diri, 
yaitu pada kerendahan hati dan kedermawanan. Konsep diri positif bersifat stabil dan bervariasi. Sehingga, orang dengan konsep diri positif dapat menerima dirinya sendiri secara apa adanya dan menerima orang lain; b) Konsep-Diri Negatif, ada dua konsep diri negatif, yaitu: (a) Pandangan mengenai dirinya sendiri benar-benar tidak teratur, dan (b) Pandangan mengenai dirinya sendiri yang terlalu stabil dan kaku (Simatupang \& Salam, 2015).

Muslimat bercadar dengan niat bercadar melihat diri mereka sebagai konsep diri yang positif. Mereka bercadar sebagai bentuk ketaatan dan ibadah kepada Allah dan agama Islam. Setiap tingkah laku muslimat bercadar berperilaku sesuai dengan ajaran agama mereka (religion self-concept), artinya perilaku komunikasi yang mereka lakukan harus tetap sesuai konsep diri yang telah terbentuk di dalam diri mereka. Selain itu dengan memakai cadar para informan tidak lantas merubah perilaku komunikasi mereka dalam hal tingkat membuka diri (self disclosure) dan percaya diri (Self confidance) dalam melakukan komunikasi pada penggunaan media sosial.

\section{Motif Muslimat Bercadar dalam Penggunaan Media Sosial}

Mereka aktif atau pasif dalam penggunaan media sosial memiliki alasan masingmasin, meskipun informan yang peneliti temukan adalah muslimat cadar yang kebanyakan pasif dalam penggunaan media sosial. Sebagai pengguna digital natives, para informan dapat menggunakan media sosial dalam satu waktu. Informan mendapat dengan mudah informasi-informasi yang dibutuhkan dan terhubung karena kemudahan akses teknologi digital. Sehingga informasi kajian-kajian yang dibagikan sebagai pengetahuan bagi orang lain dapat memperkuat ilmu agama dan menjaga ukhuwah.

Because of motive adalah motif karena, informan menggunakan media sosial mempunyai motif karena yang mengacu pada masa silam. Alasan menggunakan media sosial karena pengalaman pada masa lampau sehingga mendorong informan untuk menggunakan media sosial. Dan in-order-to-motive adalah motif untuk, yang mana penggunaan media sosial oleh para informan karena mempunyai tujuan untuk yang dicapai pada masa yang akan datang.

Tabel 3. Motif Penggunaan Media Sosial oleh Muslimat Bercadar

\begin{tabular}{|c|c|c|}
\hline Informan & Because Motive & In-Order-to-Motive \\
\hline RA & $\begin{array}{l}\text { - Facebook memperoleh dan membagi } \\
\text { kajian ilmu agama. } \\
\text { - WhatsApp dan Line untuk berkomunikasi } \\
\text { dengan keluarga, teman, dan pelanggan. }\end{array}$ & $\begin{array}{l}\text { - Penggunaan media sosial } \\
\text { Facebook untuk sarana promosi } \\
\text { produk penjualan dan } \\
\text { menambah pengetahuan tentang } \\
\text { kajian agama. }\end{array}$ \\
\hline $\mathrm{RN}$ & $\begin{array}{l}\text { - Penggunaan media sosial Facebook untuk } \\
\text { memperoleh informasi tentang kajian dan } \\
\text { masakan. }\end{array}$ & $\begin{array}{l}\text { - WhatsApp untuk promosi jualan } \\
\text { di grup dan komunikasi dengan } \\
\text { kelompok. } \\
\text { - Menambah pengetahuan tentang } \\
\text { kajian agama. }\end{array}$ \\
\hline
\end{tabular}




\begin{tabular}{|c|c|c|}
\hline Informan & Because Motive & In-Order-to-Motive \\
\hline RS & $\begin{array}{l}\text { - WhatsApp untuk penyampaian informasi } \\
\text { dan kajian ke grup serta komunikasi. }\end{array}$ & $\begin{array}{l}\text { - Penggunaan Instagram sebagai } \\
\text { hiburan. } \\
\text { - Menambah pengetahuan tentang } \\
\text { kajian agama. }\end{array}$ \\
\hline ST & $\begin{array}{l}\text { - Penggunaan WhatsApp sebagai media } \\
\text { komunikasi. }\end{array}$ & $\begin{array}{l}\text { Penggunaan WhatsApp } \\
\text { memberikan informasi kajian di } \\
\text { grup dan informasi kegiatan } \\
\text { sosial serta mengajak dan } \\
\text { membujuk untuk tentang } \\
\text { pemahaman agama Islam. }\end{array}$ \\
\hline MR & $\begin{array}{l}\text { - Penggunaan Facebook membagikan ilmu } \\
\text { kajian secara ilmiah untuk berbagi ilmu } \\
\text { dan pengetahuan dan interaksi dengan } \\
\text { keluarga. Media sosial WhatsApp untuk } \\
\text { berkomunikasi dengan keluarga dan } \\
\text { pelanggan. }\end{array}$ & $\begin{array}{l}\text { - Penggunaan Facebook untuk } \\
\text { promosi usaha keahlian jahit. } \\
\text { - Menambah dan memperdalam } \\
\text { kajian tentang agama. }\end{array}$ \\
\hline MA & $\begin{array}{l}\text { - Penggunaan WhatsApp untuk memberi } \\
\text { informasi secara cepat kepada rekan } \\
\text { kerja, dan untuk berkomunikasi serta } \\
\text { untuk mengefisienkan pekerjaan. }\end{array}$ & $\begin{array}{l}\text { Penggunaan WhatsApp untuk } \\
\text { memperoleh informasi tentang } \\
\text { kajian dan informasi pekerjaan. }\end{array}$ \\
\hline NS & $\begin{array}{l}\text { - Aplikasi Line untuk berkomunikasi } \\
\text { dengan teman-teman. Aplikasi WhatsApp } \\
\text { untuk berkomunikasi dengan keluarga. }\end{array}$ & $\begin{array}{l}\text { - Penggunaan WhatsApp untuk } \\
\text { pendidikan memperoleh ilmu } \\
\text { kajian agama Islam, akhlak } \\
\text { aqidah. } \\
\text { - Penggunaan WhatsApp } \\
\text { membagi kegiatan di pondokan } \\
\text { serta hiburan. }\end{array}$ \\
\hline WD & $\begin{array}{l}\text { - Penggunaan media sosial Facebook dan } \\
\text { Line untuk tetap dapat menjaga ukhuwah } \\
\text { sesama muslimat baik yang bercadar } \\
\text { maupun yang tidak bercadar. }\end{array}$ & $\begin{array}{l}\text { - Penggunaan Facebook untuk } \\
\text { memperoleh kajian agama Islam } \\
\text { untuk pengetahuan dan } \\
\text { keyakinan diri. }\end{array}$ \\
\hline
\end{tabular}

Sumber : Hasil Penelitian

Motif para informan memberikan gambaran dan menjelaskan tujuan-tujuan dari muslimat bercadar dalam penggunaan media sosial. Menurut Sciffman \& Kanuk (dalam Angkari, 2013) menjelaskan, motif adalah "The driving force within individuals that impels them to action," yang berarti suatu kekuatan penggerak dalam diri seseorang yang memaksanya untuk bertindak atau melakukan sesuatu. Apa yang dipikirkan seseorang, dirasakan, kebiasaan-kebiasaan baru, semuanya dipengaruhi oleh keinginankeinginan untuk mencapai tujuan yang diperjuangkan (kebutuhan). Media sosial yang sering dan banyak digunakan dari muslimat bercadar yang penulis temui sebagai pengguna yaitu Whatsapp, Facebook, Instagram, dan Line. 
Tabel 4. Alasan Penggunaan Media Sosial oleh Muslimat Bercadar

\begin{tabular}{ll}
\hline Media Sosial & Alasan Penggunaan \\
\hline WhatsApp & WhatsApp banyak dimiliki oleh \\
& pengguna digital termasuk muslimat \\
& bercadar sebagai media sosial yang \\
& dapat mudah dilakukan dalam \\
& berkomunikasi baik menyampaikan \\
& pesan dan informasi \\
Facebook & Facebook sering dijadikan peluang \\
& untuk promosi bagi muslimat \\
& bercadar yang mempunyai usaha \\
& dagang dan juga penunjuk identitas \\
& diri dengan pembaharuan status pada \\
& timeline serta memperoleh kajian \\
& ilmu agama \\
& Instagram merupakan salah satu \\
& media sosial yang memiliki banyak \\
& fitur digunakan oleh muslimat \\
bercadar sebagai hiburan dengan \\
melihat kiriman favorit, video \\
pendek, serta info-info kajian, berita. \\
Line yang digunakan muslimat \\
bercadar yang memiliki akun line \\
untuk berkomunikasi dengan \\
keluarga dan sanak saudara (lebih \\
kepada remaja, keponakan).
\end{tabular}

Sumber : Hasil Penelitian

Penggunaan media sosial muslimat bercadar tidak jauh berbeda dengan orang lain yang menggunakan media sosial untuk keperluan dan kebutuhan individu. Jika orang senantiasa membagi apapun di media sosial, muslimat bercadar yang dijadikan informan lebih menyenangi membagi kajian ilmu agama Islam dan melakukan promosi usaha dengan berjualan daring. Walaupun terlihat fenomena muslimat bercadar yang eksis dan mengunggah swafoto ke media sosial, namun membagi kajian ilmu agama juga sering dilakukan di media sosial. Setiap muslimat bercadar juga memiliki motif masing-masing dalam penggunaan media sosial.

Untuk menggambarkan seluruh tindakan seseorang, Schutz mengelompokkan motif dalam dua kategori, yakni In-order-to-motive yaitu motif yang merujuk pada tindakan di masa yang akan datang. Tindakan yang dilakukan oleh seseorang pasti memiliki tujuan yang telah ditetapkan dan because motive, yaitu tindakan yang merujuk pada masa lalu. Tindakan yang dilakukan oleh seseorang pasti memiliki alasan dari masa lalu ketika ia melakukannya. Fenomenologi Schutz merupakan tawaran akan cara pandang baru terhadap fokus kajian penelitian dan penggalian terhadap makna yang terbangun dari realitas kehidupan sehari-hari yang terdapat di dalam penelitian secara khusus dan dalam kerangka luas pengembangan ilmu sosial (Putra \& Febrina, 2019). 
Jika motif dihubungkan dengan konsumsi media sosial, berarti segala alasan dan dorongan dalam diri manusia yang menyebabkan seseorang menggunakan media sosial dan tujuannya menggunakan media sosial tersebut. Seleksi terhadap media yang dilakukan oleh khalayak disesuaikan dengan kebutuhan dan motif. Motif penggunaan media sosial oleh muslimat bercadar dengan menggunakan beberapa akun dan aplikasi media sosial untuk pemenuhan kepuasan menjadi alasan muslimat bercadar dalam penggunaan media sosial, peneliti temukan di lapangan seperti halnya teori uses and gratification (penggunaan dan kepuasaan).

Penggunaan dan kepuasan orang bergantung pada informasi yang diberikan media untuk memenuhi kebutuhan tertentu atau untuk mencapai tujuan tertentu, tetapi orang tidak bergantung pada semua media secara sama dan merata. Teori uses and gratification ini tidak tertarik pada apa yang dilakukan media pada diri orang, melainkan tertarik pada apa yang dilakukan orang terhadap media. Anggota khalayak dianggap secara aktif menggunakan media untuk memenuhi kebutuhannya (Rakhmat, 2007).

Orientasi motif muslimat bercadar adalah kebutuhan kognitif akan informasi aktual. Motif penggunaan media sosial muslimat bercadar juga untuk keyakinan agama serta mencari ilmu kajian agama yang banyak dibahas oleh ustaz-ustaz yang memiliki pengetahuan agama Islam yang luas. Penggunaan media sosial oleh muslimat bercadar juga untuk tetap menjaga ekslusivitasnya dan tidak memperlihatkan diri dengan mengunggah foto-foto swafoto ke akun media sosial. Sesuai pendapat Wilson (dalam Pramiyanti, et al., 2014) bahwa salah satu kebutuhan terbesar manusia yaitu memenuhi kebutuhan kognitifnya. Kebutuhan ini berkaitan erat dengan motif seseorang untuk memperkuat atau menambah informasi, pengetahuan, dan pemahaman mengenai lingkungannya. Kebutuhan pemahaman agama muslimat bercadar juga untuk selalu menjaga aurat serta mematuhi perintah agama dan menghindari fitnah.

\section{Simpulan}

Penggunaan media sosial oleh muslimat bercadar memberi pengalaman terbaik berupa promosi usaha, mempermudah pekerjaan, informasi, diskusi, bertemu teman lama, serta mendapat teman baru. Sedangkan pengalaman tidak menyenangkan yaitu penghakiman dan perundungan siber serta penilaian melalui komentar pada status di media sosial. Pengaruh orang terdekat dan lingkungan merupakan faktor yang dapat membentuk konsep diri muslimat bercadar. Sikap dan pandangan dari orang tua, saudara dan lingkungan, akan menjadi bahan informasi untuk menilai siapa dirinya. Manusia menilai dirinya berdasarkan apa yang dia alami dan dapatkan dari lingkungan. Lingkungan yang memberikan sikap baik dan positif, memunculkan perasaan berharga sehingga tumbuh konsep diri positif. Penggunaan media sosial oleh muslimat bercadar juga membantu mereka untuk istikamah dengan cadar dan memperoleh ilmu-ilmu kajian keagamaan yang banyak dibagikan di media sosial. 
Secara umum penggunaan media sosial oleh muslimat bercadar tidak berbeda dengan pengguna lainnya. Penggunaan media sosial untuk interaksi dan komunikasi. Penulis menyarankan agar muslimat bercadar yang aktif menggunakan media sosial dapat menjadikan penggunaannya sebagai pengontrol diri dalam hakikatnya bercadar. Banyak muslimat yang memutuskan untuk bercadar dan banyak pula komunitaskomunitas niqabers atau hijabers yang mengirim foto di media sosial dengan tujuan dakwah. Muslimat yang ingin berdakwah, hendaknya berdakwah dengan tidak memperlihatkan fotonya di media sosial serta membagi kajian yang tidak menyinggung keagamaan orang lain.

\section{Referensi}

Angkari, S. (2013). Motif Masyarakat Surabaya dalam Menonton Program Good Morning Hard Rockers on SBO. Jurnal e-Komunikasi, 1(3).

Angkari, S. (2013). Motif Masyarakat Surabaya dalam Menonton Progam Good Morning Hard Rockers on SBO. Jurnal e-Komunikasi, 1(3).

Hafiar, H. (2012). Cacat dan Prestasi melalui Pengalaman Komunikasi Atlet Penyandang Cacat (Studi Fenomenologi Mengenai Konstruksi Makna Kecacatan dan Status Sebagai Atlet Berprestasi melalui Pengalaman Komunikasi Atlet Penyandang Cacat Berprestasi di Bandung. Indonesian Jounal of Dialectics IJAD. Vol. 2 (1): 308-309.

Iskandar, A.S (2013). Konstruksi Identitas Muslimat Bercadar. Jember: Universitas Jember.

Jamal, Z. (2013). Fenomena Wanita Bercadar (Studi Fenomenologi Konstruksi Realitas Sosial dan Interaksi Sosial Wanita Bercadar). Surabaya: Universitas Pembangunan Nasional "Veteran" Jawa Timur.

Mulyana, D. (2004). Ilmu Komunikasi: Suatu Pengantar. Bandung: Remaja Rosda Karya.

Muthahhari, M. (2012). Cadar Tuhan: Duduk Perkara Hijab Perempuan. Jakarta: Citra.

Novri, M. S., \& Yohana, N. (2016). Konstruksi makna cadar oleh wanita bercadar jamaah pengajian masjid Umar bin Khattab kelurahan delima kecamatan tampan pekanbaru. Jom Fisip, 3(1), 1-12.

Pramiyanti, A., Putri, I. P., \& Nureni, R. (2017). Motif remaja dalam menggunakan media baru (studi pada Remaja di Daerah Sub-Urban Kota Bandung). Komuniti: Jurnal Komunikasi dan Teknologi Informasi, 6(2), 95-103.

Puspanegara, V.A. (2016). Perilaku Komunikasi Perempuan Muslim Bercadar Di Kota Makassar (Studi Fenomenologi). Makassar: Universitas Hasanudin.

Putra, A. M., \& Febrina, A. (2019). Fenomena Selebgram Anak: Memahami Motif Orang Tua. Jurnal Aspikom, 3(6), 1093-1108.

Rakhmat, J. (2007). Psikologi Komunikasi. Bandung: Remaja Rosda Karya.

Sari, F.H., Lilik, S., \& Agustin, R.W. (2014). Studi Fenomenologi Mengenai Penyesuaian Diri pada Wanita Bercadar. WACANA, 6(1). 
Simatupang, F.F., \& Salam, N.E. (2014). Fenomena selfie (self portrait) di instagram (Studi fenomenologi pada remaja di Kelurahan Simpang Baru Pekanbaru). Jurnal Online Mahasiswa (JOM) Bidang Ilmu Sosial dan Ilmu Politik, 2(1), 1-15.

Talani, N. S. (2014). Esensi Interaksi Visual dalam Dunia Facebook yang Virtual. Jurnal komunikasi, 9(1), 69-84.

Wirman, W. (2016). Citra \& Presentasi Tubuh Fenomena Komunikasi Perempuan Bertubuh Gemuk. Pekanbaru: Alaf Riau.

Zulfa, Y., \& Junaidi, A. (2019). Studi Fenomenologi Interaksi Sosial Perempuan Bercadar di Media Sosial. Koneksi, 2(2), 635-641. 